Wojciech Misztal

Studia Theologica Varsaviensia

\title{
The Old Order Of Captivity Of Sin And Death: A Man Before Coming Of Christ*
}

\section{A Man Captivated By Powers Of Sin And Death (Introduction)}

We can talk about a life of a man in many ways, about his current situation. A man experiences different captivations and restrictions. From the perspective of faith, we will be discussing the need of salvation, redemption and liberation of a man by Christ. It was true for people living before His coming and fulfilment of His paschal mystery. It remains true nowadays as well. And it is true for a man believing in Christ. Let us see what God himself says about his Revelation. We will not be able to entirely deal with this issue. The point of view, which we will attempt to present, deserves the attention. Due to, among others, its topicality for a contemporary man.

"Because everybody sinned and they are deprived of God's grace, but they obtain justification for free, from His grace, by salvation, which is in Jesus Christ" (Rom 3:23-24). As it seems, this sentence perfectly reflects a situation of a man in temporality, that is in the current order of the economy of salvation. A man experiences here a peculiar 'participation' in the order, which actually and perfectly conditions his existence, his being. Despite all his efforts, he must eventually admit that he is not able to convert himself into an ideal being or his temporality in paradise. Despite his exceptional, inimitable positions, through his restriction a man remains like other created beings. He experiences a continual conflict in himself, a struggle between good and evil. What is more, by himself, that is being only stranded, he is not sure of victory over the latter. Sin unfolds its power over a man so many times. A man remains a successor of Adam, Abel and Cain. He experiences that his being is permeated by: order of spirit and order of matter, thoughts and desires absolutely noble but also 
these lowest ones, gestures and deeds worthy of a hero and these appropriate for a coward. A man is such. Our world is such.

This is a mystery of a man and the world which co-exists with a mystery of Christ's presence. The latter permeates, transforms the former. In other words, we are not alone. We are not stranded to pessimism or mirages of self-sufficiency. Christ is with us ${ }^{1}$. We cover in Christ, in Him and through Him the meanders of history, in which - just like in ourselves - there is already a current order of new heaven and new earth: if someone [is] in Christ, [he/she is] a new being, the old one has gone, the new one has become (2Cor 5:17; cf. 2P 3:13) ${ }^{2}$. Those who were called to become the citizens of heaven (cf. Phil 3:20), do not leave their earthly homeland to itself with its difficulties and problems. They accept Divine decisions. Being aware of temporality and complexity of the situation at the current stage of the economy of salvation, they await with faith for the eventual realisation of God's plans. With love and hope, awaiting the return of the Saviour in glory, they answer in Christ, through Him and in Him, His call: they are to represent in the world, transfer a message of salvation and eternal life to others (cf. 2Cor 5:20). They are to transform and cure. In a nutshell, they are called to participate in God's mystery (cf. e.g. Eph 1:3ff).

We can reflect the current situation of a man in temporality by situating him with reference to sin and death. If we talk about the latter, then it is difficult not to mention the first man. In this way we face, e.g. the expression of this type "in death" (en thanatô) and "in Adam" (en tô Adam). In the temporal order of things good and evil can blend somehow and even permeate (cf. e.g. Rom 7:15nn). This paradox will be described e.g. by means of expression of this type "in body" (en tô sômati, en sarki) and "in law" / "in Law" (en tô nomô). Apparently, the provision of a more systemic vision or the synthesis of definite aspects corresponding to our life in temporality will not be possible at the selection and during the discussion of particular expressions. In such a case, it would be necessary to also analyse, on the one hand, other wordings encountered e.g. in Corpus

1 Christ's presence overpowers everything. Cf. e.g. 1 Cor 8:6 and Cor 10:4. These texts describe the creation of the word and the Exodus of Egypt and the way to the Promised Land. These two are the main points for the act of salvation. As you may easily notice, they do not belong to the economy of the New Covenant.

2 Let us return here, even if it does not concern Corpus paulinum directly, to the last gesture of Christ, that which is describes by St. Luke. The gesture is so precious, e.g. for the icons of the East or medieval cathedrals of the West. "He blessed them" (Greek: en tô eulogein auton autous, Lk 24:5). The Acts of the Apostles start from this gesture. The acts of Christians do not only begin from this gesture but progress permanently. This gesture is related to the beginning of a new stage of history. It takes place 'in' Christly "blessing" (cf. en tô eulogein). 
paulinum in the so-called authentic epistles of St. Paul ${ }^{3}$. On the other hand, the very issues related to the afore-mentioned wordings, even if in view of the elements creating them, seems to be immensely broad and complicated. In the first and the second case we would have to exceed the scope of this paper. Most certainly, however, at least a short analysis of the wordings of such type "in death," "in Adam," "in body" (en tô sômati, en sarki) and "in law" / "in Law" (en tô nomô) will be interesting at least due to totality of panorama of our temporal life.

\section{A Man - A Successor of Adam: the Wording "In Adam"}

In the New Testament we will find the wording "in Adam" only once, and namely in 1Cor 15:22: "just like everybody dies in Adam, then everybody will be restored in Christ." It should not be surprising, since the very word "Adam" is seen only 9 times in this collection of writing ${ }^{4}$. The meaning of the term discussed could not be overestimated, however, e.g. at least for the theology of the New Testament ${ }^{5}$.

It seems that diverse speculations concerning the person of Adam or the role he was supposed to act in the history of the world and humanity, constitute something enormously significant for the thought and Hebrew theology prior to and contemporary for St. Paul. ${ }^{6}$ To some extent the Apostle could take certain

3 Rom, 1-2Cor, Phil, 1 Thess and Philemon are believed in our considerations to be the socalled the authentic epistles of St. Paul. Cf. e.g. E.R. Martinez, La vita cristiana e la spiritualitâ secondo san Paolo (ad usum studenti), Rome 1992, 4 f on the issue of the division of particular documents included in Corpus paulinum into different groups (also including the issue of the so-called the authentic epistles of St. Paul). Certainly, the issue of the division of the documents constituting Corpus paulinum into groups (also including the problem of the so-called the authentic epistles) is not easy and the particular attempts of classifying the epistles included in Corpus paulinum is still a subject of discussion and research. Out of necessity, we confine ourselves to a selection of one of the solutions. In this article we will rely mostly on the texts copied from the so-called authentic epistles of Paul the Apostle.

4 Cf. Rom 5:14ab; 1Cor 15:22.45ab; 1 Tim 2:13.14 as well as Lk 3:38 and Jude 14. As for the word discussed, cf. e.g. L.J. Kreitzer, Adam and Christ, 9; J. Fitzmyer, Pauline Theology, in: The New Jerome Biblical Commentary, Edited by Raymond E. Brown etc., London 1992, 1385f; J. Jerernias, Adam, TWNT I, 141f and Vocabulaire de théologie biblique publié sous la direction de Xavier Léon-Dufour etc., Paris 1971, $18 f$.

5 We could pose a question here as well if the word "Adam" was a proper name or not for St. Paul the Apostle, cf. e.g. L.J. Kreitzer, op. cit., 9.

6 E.g. according to B. Rey, Créés dans le Christ Jésus, La création nouvelle selon saint Paul, Paris 1966, 75. In the times of the Apostle Adam was at the centre of a great deal of research: 
elements here for his own vision of the history of salvation? ${ }^{7}$. Let us observe here as well that it is possible that the wording "in Adam" (or alternatively similar expressions to this one if they existed) served for St. Paul to some extent, particularly theologically, for the model of the formulas of this type "in Christ." Anyway, it is an indisputable fact that the antithesis - the juxtaposition between Adam and Christ is not least something unknown to the Apostle (cf. Rom 5:12-21; 1Cor 15:20-22.45-49) ${ }^{9}$. Adam and Christ mean two cardinal points as far as e.g. salvific work is concerned. We could even say about, with reference to their meaning, about two beginnings of histor ${ }^{10}$. We have the first Adam and

people wanted to understand and respect him as the first man in history and in human destiny (as for St Paul the author sees references to such speculations, e.g. in Rom 5:14: "he is a type of The One, who was to come"). Cf. also H.H. Schade, Apokalyptische Christologie bei Paulus. Studien zum Zusammenhang von Christologie und Eschatologie in den Paulusbriefën, Göttingen 1981, 74: "Die Bestimmtheit der Menschen durch Adam ist eine im Judentum verbreitete Annahme: Adam bringt durch seine Sünde das Todsverhängnis und verantwortliche Tal über die Menschheit, wobei Auffassungen über die Sünde als Verhängnis und verantwortliche Tat, auch in derselben Schrift (4Esr; syBar), unausgeglichen nebeneinander stehen. Während das „ in” $(1 \mathrm{~K} 15,22)$ durch jüdische wie gnostische Parallelen abgedeckt wird, hat das "durch" (IK 15,21) nur in jüdischen, nicht aber in gnostichen Parallelen volle Entsprechung.”

7 H. Schlier, Grundzüge einer paulinischer Theologie, Freiburg 1978, 175.

8 Cf. e.g. Ibid., also in G. Bornkamm, Der Römerbrief als Testament des Paulus, in: G. Bornkamm, Geschichte und Glaube. 2 Teil, München 1971, $133 f$.

9 According to F. Amiot, Lire saint Paul, Paris 1962, 50, by St. Paul "toutes les options, antithéses ou contradictions apparentes, se résolvent dans la considération du renouvellement apporté par le Christ et de l'obligation d'y collaborer, dans une vie dominée el constamment inspirée par la foi et par l'action de l'Esprit de Dieu” (cf. Rom 2:28-29; 1Cor 7:19; Gal 6:15), and different Pauline antitheses "se réfèrent r'une autre plus fondamentale dont elles sont les expressions partielles, l'antithèse entre les deux chefs de l'humanité, Adam et le Christ." Cf. G. Eichholz, Die Theologie des Paulus im Umriß, Neukirchen 1972, 189: "Ich hebe noch einmal hervor; daß Paulus, wenn er das Evangelium verkündigt, ein Ereignis verkündigt. (...) So erzâhlt Paulus in Romand 5,12-21 die Geschichte des Handels Gottes in Jesus Christus in der Sprache der Adam-Christus-Typologie" (he also cites B. Pascal, Pensées, 523: “Toute la foi consiste en Jésus Christ et en Adam"). Cf. H. Schlier, op. cit., 175. As for the antithesis - the juxtaposition of Adam / Christ and the expression of this type "with Christ" (son Christô), cf. W. Grundmann, son etc., TWNT 7, 784f.

10 Cf. e. g., about Christ, 2Cor 5:17: "hence if someone [is] in Christ, [he/she is] a new being: [this what is] old has gone, and the new has become." Cf. also E. Käsemann, Leib und Leib Christi. Eine Untersuchung zur paulinischen Begrifflichkeit, Tübingen 1933, 184: "Christus ist die Erfüllung der Zeiten und steht Adam gegenüber als die eschatologische Neuschöpfung. Das en Christô bedeutet als „im Geiste” das Stehen in Gottes Neuschöpfung, das selber neue Schöpfung ist;" cf. H. Schwantes, Schöpfung der Endzeit. Ein Beitrag zum Verständnis der Auferweckung bei Paulus, Stuttgart 1963, 70f; U. Luz, Das Geschichtsverständnis des Paulus, München 1968, 307.194; 
the last Adam (1Cor 15:45) ${ }^{11}$, the first man and the last Man, the earthly man and the heavenly Man (1Cor 15:47f $)^{12}$.

1Cor 15:47-49 (cf. In 45-46 and Rom 5:12-21), also seems to follow this view, according to which we have two groups of people, which are led by Adam and Christ $^{13}$ :

what [a man taken] from earth

then [people taken] from earth as well

how we were carrying we will be carrying

the image of [a man taken from earth] what [a man taken] from heaven

then [people taken] from heaven as well

the image [of a man taken] from heaven

Since the coming of the Saviour a man can leave Adam's domain (everyone dies in Adam, 1Cor 15:22) and proceed to a domain, to Christ's kingdom (everyone will be animated in Christ, ibid.) ${ }^{14}$. Belonging to the first Adam means submission to the power of death and this - paradoxically - because of the one, who was to provide life for the entire humanity. Belonging to the second Adam, to Christ, is to possess a guarantee of endless life - thanks to the one, who was

H. Schlier, Der Brief an die Galater übersetzt und erklärt von Heinrich Schlier, Göttingen 1971, 276; A. Oepke, Der Brief des Paulus an die Galater Zweite, verbesserte Auflage, Berlin 1960, 30 and G. Bornkamm, Taufe und neues Leben bei Paulus, $34 \mathrm{f}$.

11 According to F. Prat, La théologie de saint Paul, vol. 2, Paris 1933, 360, the way in which the formulas "in Christ" are constructed by St. Paul indicates that the Apostle "ne considère pas la personne individuelle de Jèsus, mais sa fonction de Messie, sa qualité de second Adam, en un mot son caractère représentatif." Cf. W, Grundmann, art. cit., 789.

12 W. Grundmann, art. cit., 789, sees "incorporating people" in Adam and Christ (korporativen Personen), cf. also J. Jeremias, Adam, TWNT 1, 141; J. Gnilka, Der Brief an die Philipper: Auslegung von Joahim Gnilka, Düsseldorf 1961, 81 (Die Ausweitung des Christusschichsal auf die Menschen hat ihre Wurzeln in der biblischen Vorstellung von der korporativen Persönlichkeit); R. Schnackenburg, Die Taufe, 459 and Die Adam-Christus Typologie (Röm 5,12-21), 38; E. Larsson, Christus als Vorbild, 74f. According to H.H. Schade, Apokalyplische, 74f, the concept of 'incorporating people' (corporate personality) could allow a better understand of the meaning of formula 'in Christ' (in particular if we would like to include relations between the Apostle and a sapiential tradition), cf. also p. 83n and M.A. Seifrid, In Christ, in: Dictionary of Paul and His Letters. Editors: Gerald E Hawthorne, Ralph P. Martin. Associate Editor: Daniel G. Reidi, Downers Grove-Leicester 1993, 434 and 436; H. Schlier, Grundzüge..., op. cit., 175f; W. Thüsing, Per Christum in Deum, 66 and 74n; F. Froitzheim, Christologie und Eschatologie bei Paulus, Würzburg 1979, 193 and 210; P. Hoffmann, Die Toten in Christus. Eine religions-geschichtliche und exegetische Untersuchung zur paulinischen Eschatologie, Münster 1966, 310; R. Schnackenburg, Todes- und Lebensgemeinschaft mit Christus, $379 \mathrm{f}$.

13 Cf. G. Eichholz, op. cit., 172 and B. Rey, op. cit., 167.

14 H. Schlier, Grundzüge..., op. cit., 175. Cf. F. Prat, op. cit., vol. 2, 361 and vol. 1, 160f. Cf. also e.g. Rom 6:8: "because if we died with Christ, [then] we believe that we will be living with Him." 
to die for people (cf. e.g. 1Cor 15:22 and Rom 5:10.17) ${ }^{15}$. Certainly, dependence, communion, solidarity "for life" in Christ compensates much more than dependence, solidarity "for death" in Adam (cf. e.g. Rom 5:12-21; 6:1-11) ${ }^{16}$. As for 1Cor 15:22, we can present the antithesis Adam - Christ in the following way: ${ }^{17}$ because if everybody dies in $\mathrm{Adam}^{18}$ then everyone will be animated in Christ

Because Adam incorporates, "comprises" the entire humanity in himself as its progenitor and the first head, because all people are his successors, hence the expression "in Adam" from 1Cor 15:22 may denote not only "because of Adam," but also "belonging to Adam," "remaining dependent on Adam," "participating in his fate," "as a result of community with him" (cf. Rom 5:12-21). Hence, we will be able to talk about a peculiar order of things, as the wording "in Adam" reflects. As it is demonstrated, at least, in 1Cor 15:22 this order is not indifferent to us at all. One of its basic features is that a man is subject to death: "everyone dies in Adam" (1Cor 15:22).

\section{A Man - Submitted to Death: the Wording "In Death"}

In the so-called authentic epistles of St. Paul, we observed the expressions of such a type "in death" only twice: in Rom 5:21 and in 2Cor 11-23 ${ }^{19}$. Seeing that in the last of two pericopes the wording often in danger of death (en thanatois pollakis)

15 Cf. A. Deissmann, Paulus. Eine kultur- und religionsgeschichtliche Skizze. Zweite völlig neubearbeitete und vermehrte Auflage, Tübingen 1925, 140 and H, Schlier, Grundzüge..., op. cit., 175.

16 F. Amiot, Les idées maîtresses de saint Paul, Paris 1959, 222. Cf. P.H. Menoud, Le sort des trépassés dáprès le Nouveau Testament, Neuchâtel-Paris 1945, 32 and H. Frankemölle, Das Taufiverständnis, $36 \mathrm{f}$.

17 According to F. Prat, op. cit., vol. 2, 361, the best remark to the formula "in Christ" is constituted by 1 Cor 15:21-22.

18 Cf. B, Rey, op. cit., 49. The author emphasises the fact that "they die" is grammatically an indicative mood of the present tense. It means that the Apostle signifies the whole of humanity. In this context this author reminds us that the word tagma ("group") recalls the idea, e.g. of belongingness to a specific, strictly hierarchised group (e.g. a military one), where we are under a particular chief, we are strictly dependent on him and share his fate. Hence the expression "in one's order" / "in own group" from 1Cor 15:23 would indicate, according to this author that the people of all times are mentioned in Corinthians. According to A. Feuillet, Mort du Christ et mort du chrétien, 487.512, the wording "everyone dies in Adam" from 1Cor 15:22 corresponds to the truth, fundamental for the history of salvation and for the life of each man that we all dies in Christ on Calvary and in the sacrament of (cf. 2Cor 5:5; Rom 6:11; Gal 2:20 as well as 1 Thess 4:16 and 1Cor 15:18).

19 As for the New Testament, see also J 3:14 and Revelation 6:8. 
refers only to the person of St. Paul and constitutes a part of the description of circumstances, in which he fulfils his apostolic service, we restrict here only to several remarks related to Rom 5:21.

The one, who was to provide life for the entire humanity, namely Adam, left his heritage of sin and death: sin ruled in death (Rom 5:21, cf. also e.g. Rom $5: 12)^{20}$. Sin stepped into the history of the world and reached all people with its power. In a sense it even started ruling in the world instead of $\mathrm{God}^{21}$, ruling such like death itself (cf. Rom 5:21, 14:17). The ruling of sin and death starts by Adams's crime ${ }^{22}$. Whereas by Christ those, who belong to Him, who are in Christ, experience salvation. They become liberated from the reign of sin and death. What is more, they will rule together with their $\operatorname{Lord}^{23}$, with the One, in whom there is a gift and grace of eternal life: because the retaliation of sin is death, but grace given [from] God [is] eternal life in Jesus Christ our Lord (Rom 6:23). We have, then, as if two eras, two orders, and they are of common importance, the First starts for the humanity (and for the whole world) with Adam's crime. His economy leads through sin to death ${ }^{24}$. The second order opens before people together with Christ ${ }^{25}$, through Him and in Him. His economy leads to eternal life:

$\begin{array}{ll}\text { sin } & \text { those who receive abundance of grace and a gift of justice } \\ \text { reigned } & \text { will rule } \\ \text { in death } & \text { in life }{ }^{26} .\end{array}$

20 Rom 5:12: "therefore, so when a sin got through one man and into the world, and death through sin, and in this way, death transferred on all people, because they all sinned."

${ }^{21}$ Cf. L. Cerfaux, Le chrétien dans la théologie de saint Paul, Paris 1962, 382.381, where the author writes on Rom 5:21 in the following way: Rz 5121: "Des deux couples antithétiques, c'est le second, "mort-vie", qui règle le mouvement de la pensée, l'usage du verbe "régner" l'indique sufisamment" (Rom 5:17.21).

22 Cf. e.g. Rom 5:15: But not in the same way as with crime but with the gift of grace; because of the crime of one person death was brought to all, and then how more abundant will the grace and gift of God affect everyone, graciously given by one Man, Jesus Christ. Cf. M. Zerwick, Analysis philologica Novi Testamenli Graeci, Editio quarta (nova impressio), Rome 1984, 345.

23 Cf. e.g. 1 Thess 4:17; 2 Tim 2:12; 1Cor 6:2-3, 4:8.

24 Cf. e.g. J.J. Scott, Life and Death, 554; L. Morris, Sin, Guilt, 878; A. Bonora, Morte, in: Nuovo dizionario di teologia biblica a cura di Pietro Rossano etc., Torino 1994, 1023 and also S. Virgulin, Peccato, in: Nuovo dizionario di teologia biblica a cura di Pietro Rossano etc., Torino 1994, 1132.1137.

25 Cf. e.g. R. Bultmann, thanatos etc., TWNT 3, 18.

26 Cf. Rom 5:21.17. 
It is obvious that we still need a return of God in glory so that the second order could receive its ultimate dimension. However, even now, namely in temporality marked by a stigma of sin and death, those, who are in Christ, experience the result of a transfer from a domain of sin into a domain of grace ${ }^{27}$, from a domain of death to a domain of life: "(1) now there is [no] condemnation yet for those [who are] in Jesus Christ: (2) because the right of the Spirit of life in Jesus Christ released you from the right of sin and death" (Rom 8:1-2, cf. also in 24 : we are redeemed by hope).

\section{A Man - Subject to Law: the Wording of the Type 'In law' I 'In Law'}

In Corpus paulinum, in the afore-mentioned authentic epistles, we encounter the wording of the type "in Law" / "in law" (Greek. en nomô) in the following texts $^{28}$ : Rom 2:12 ("because those, who sinned without Law, will also die without Law, and those who sinned in Law, will be judged by Law"29); Rom 2:20 ("the educator of the unskilled, the teacher of cavemen, having an expression of knowledge and truth in Law"); Rom 2:23 ("who boast in Law, by violating Law you insult God"); Rom 3:19 ("because we know that everything Law states, is applied to those, who are in Law, so that each mouth could quieten, and the entire world had to regard itself as sinful towards God"); Rom 7:23 ("in my body I notice other law, which fights with law of my mind and conquers me in captivity under this law [literally: in law] of a sin living in my body ${ }^{30}$ ); Cor 9:9 ("because it is written in the Law of Moses"); 1Cor 14:21 ("it is written in Law"); Gal 3:11 ("and that in Law nobody reaches justification before God"); Gal 5:4 ("you broke relations with Christ, all, who seek justice in Law, fall from grace"); Phil 3:6 ("as for zeal a pursuer of the Church, as for justice, justice in law, I became impeccable").

${ }^{27}$ Cf. e.g. in Rom 6:2 "if we died in sin, how shall we still live in it?); 6,12 (may then a sin not rule in our deadly body submitting us to its lusts" and in 1Cor 15:17 "if Christ did not rise from the dead, our faith is in vain and you remain in your sins until now."

28 As for the New Testament, then the expressions of this kind are also found in the following texts: Mt 12:5; 22:36; Lk 2:23-24; 10:26; 24:44, Jude 1:45; 8:5.17; 10:34; 15:25; Acts 13:38, as for Corpus paulinum, we found the wordings discussed only in the so-called authentic texts.

29 As for the expression "in Law" in Rom 2:12 cf. also the critical apparatus.

30 As for the expression "in law of sin" in Rom 7:23, according to some witnesses of the text, there is lack of the particle en ("in"), cf. critical apparatus. 
The group with the expressions "in Law" / "in law" could be categorised as follows: Rom 7:6 ("now Law lost its power over us, we died with this [literally: in this], which kept us on a leash, so that we can serve in novelty of the Spirit, but not according to [literally: in] an obsolete letter"); Rom 8:3 ("this, however, which was impossible for Law, because a body was making it powerless [literally: in which, namely in Law, it became powerless through a body], [it was done by God]. God sent his Son in a body similar to a sinful body and for [the removal] of a sin delivered a judgment in this body which condemned a sin"); Rom 10:5 ("because Moses writes about justice, this resulting from Law: a man who obeys them, will [literally: in them] live from them"); Gal 3:12: ("Law is not from faith, but who obeys them [that is regulations, commands of Law], then he will [literally: in them] live from them") ${ }^{31}$.

All texts enumerated above can be divided into two groups. The first one comprises fragments, in which the wordings of the type: "in Law" / "in law" mean one or more books of the Old Testament. 1 Cor 9:9, 14,21 as well as probably Rom 2:20.23 and Phil 3:6 may be included here. The second group is constituted by the texts, in which the wordings of this kind: "in Law" / "in law" serve to reflect the ideas, as if we could say, of certain order or dependence on it (cf. e.g. Gal 5:4: "you were broken away from Christ, you, who are searching justice in Law, fell from grace") ${ }^{32}$. In our case we need to include: Rom 2:12; 3:19; 7:23; Gal 3:11; 5:4 as well as Rom 2:20.23; Phil 3:6 $6^{33}$ and Rom 7:6; 8:3; 10:5; Gal 3:12 in the second group. Given the subject of our interests, we will confine here only to a short presentation of the texts comprising just the second group. It is also obvious that we will not be able to discuss the abundant, equally significant and complex at the same time, issue related to the term "Law" / "law" (nomos) at least in the epistles of Saint Paul the Apostle ${ }^{34}$. The attempt to classify

\footnotetext{
31 Obviously, we need to remember that in two last texts "in them" is not a synonym of "in Law" in the strict meaning of the word. A more precise definition of what the wording "in them" reflects is beyond the scope of this paper.

32 Cf. also Rom 8:2.

33 As was already outlined, the three last texts may also be included in the first group.

34 On this issue cf. e.g. H. Kleinknecht, W. Gutbrod, nomos etc., TWNT 4, 1016n, F. Thielman, Law, 529f, T.R. Schreiner, Law of Christ, 542f, L. Morlandi, Legge / diritto, in: Nuovo dizionario di teologia biblica a cura di Pietro Rossano etc., Torino 1994, 788f, H. Cazelles, Loi israélite, SDB 5, 498n, Vocabulaire de théologie biblique, 667n, S. Lyon net, Libertr cristiana e legge dello Spirito secondo san Paolo, in: I. de la Potterie - S. Lyonnet, La vita secondo lo Spirito. Condizione del cristiano. Introduzione di Y.M.J. Congar. Seconda edizione, Roma 1971, 203, F. Neugebauer, In Christus. Eine Untersuchung zum paulinischen Glaubensverständnis, Göttingen 1961, 72, A. Schweitzer, La mystique de l’Apôtre Paul, Paris 1962, 113.
} 
the texts interesting for us in accordance with the key suggested above in two groups specified above, sufficiently demonstrates the problems related to the interpretation of the word mentioned (cf. e.g. Rom 7:23).

As the Apostle writes, even if a man takes delight in God's law (Rom 7:22, cf. 7:14f), then he simultaneously notices some other law in himself. The latter one underlies a continual conflict taking place in a man in our temporality: "in my body I notice other law, which fights with law of my mind and conquers me in captivity under the law of a sin living in my body" (Rom 7:23). There is then some law of sin, which captivates Adam's successors in a way, influences them. It is in them and they are in it ("which conquers me in captivity under the law of sin being in my body," Rom 7:23).

Those, who practise Judaism and refer to Law and its regulations, have "an expression of any knowledge and truth" in Law (Rom 2:20). They boast in Law (cf. Rom 2:23) 3 $^{35}$ They are "under" Law (literally "in Law," cf. Rom 2:12: "those who are in Law"). They belong to the order of Law (cf. Rom 3:19: "because we know [that] what Law says, [it] says it to those being in Law") and that it is to such an extent that they will be judged by Law (dia nomou, Rom 2:12).

In this context we need to enumerate two interesting texts, which describe a peculiar relation between Law and life. The first of them is Rom 10:5: "because Moses writes about justice from [ec] of Law: a man who obeys them, will live in them." The second one is Gal 3:12: "because Law is not from [ec] of faith, but: who obeys them, will live in them" (cf. Phil 3:6, where St. Paul states about himself: "as for zeal a pursuer of the Church, as for justice, which [is] in Law, I became impeccable." ${ }^{36}$

There is another group of texts. They describe the antithesis between Law and Christ, between order "in Law" and order "in Christ." ${ }^{37}$ In Gal 3:11

35 Cf. Romans 2:17: "if you proudly call yourself a Jew and you completely fall back on Law and boast in God." Cf. as for Christians, e.g. Romans 5:11 ("boasting in God by our Lord Jesus Christ, through whom we obtained reconciliation now"), 1 Corinthians 1,31 ("who boasts oneself, may he boast in Lord"), 2 Corinthians 10:17 ("who boasts oneself, may he boast in Lord"); Galatians 6:14 ("as for me, may I not boast from something else but the cross of our Lord Jesus Christ"), Philippians 3:3 ("boasting in Jesus Christ and not behaving owing to bodies [literally: in body]") and Philippians 1:26 ("may your glory abound in Jesus Christ in me").

36 Cf. also e.g. The Book of Leviticus 18:5: "you'll obey my laws and my judgments. A man who obeys them, lives thanks to them" (LXX: "in them," en autois).

37 Cf. L. Cerfaux, Le Christ dans la théologie de saint Paul, Paris 1954, 376.373, H. Conzelmann, Grundriß der Theologie des Neuen Testaments, Tübingen 1987, 234, E. Lohmeyer, Grundlagen paulinischer Theologie, Tübingen 1929, 142, F. Prat, op. cit., vol. 2, 478f. Cf. also F. Neugebauer, In Christus, 92: „Das Heil en Christô stand dem Heil en nomô gegenüber (...) Paulus hat eben 
the Apostle writes: "and that in Law nobody reaches justification before God, the result from it is that the just will live from [ec] of faith" (cf. also the sources quoted above: Gal 3:12; Rom 10:5 and Phil 3:6). According to Saint Paul, if a Christian sought his justification in Law, then simultaneously he would break away from Christ and fell from grace (Gal 5:4: cf. Rom 7:6: "because now we became released from Law, having dies in it [en hô], which captivated us.") ${ }^{38}$

In conclusion, let us add one opinion, according to which the expressions of this type: "in Law" / "in law" could serve St. Paul as a sort of model for the formulas of this type: "in Christ" and their meaning and application. It would be related, for example, with multiple, strict relationships between the Old and the New Covenant (of such a type, e.g. chronological, linguistic, theological, etc.). ${ }^{39}$

\section{A Man - Physical Material Being: the Wording "In Body" (EN SOMATI And EN SARKI) ${ }^{40}$}

As the title indicates, we will stop at present on the issue related to the expressions "in body" (en sômati and en sarki). In the context above we need to mention that according to some authors the formulas of the type: "in Christ," which we come across in St. Paul the Apostle, are related to the Pauline concept of "body of Christ" (sôma Christou, cf. e.g. 1Cor 12:27) ${ }^{41}$.

nicht nur in Antithesen geredet, ging es ihm doch auch weniger um den Gegensatz, sondern darum, daß das eschatologische Heil in Christo Jesu geschehen ist, geschieht und geschehen wird."

${ }_{38}$ Cf. also Romans 8:3 ("because this what was impossible for Law, in which helplessness through body, God [did it] by sending his Son in similarity to body of sin") and e.g. Romans 3:24 ("the justified for nothing by His grace through redemption, which is in Jesus Christ"); 5:9 (all the more justified in His blood we will be redeemed by Him from wrath"), 1 Corinthians 5:4 ("rising in the name of Our Lord Jesus").

39 Cf. e.g. W. Schmauch, In Christus. Eine Untersuchung zur Sprache und Theologie des Paulus, Güthersloh 1935, 161f; E. Lohmeyer, Grundlagen paulinischer Theologie, 23 and 142n; A. Schweitzer, La mystique de l'Apôtre Paul, 113; F. Neugebauer, In Christus, 78 (Diesen Sachverhalt, nämlich daß Christus das Ende des Gesetzes ist, bringt Paulus öfteren in präziser und explikativer Weise durch die Formel 'in Christo (Jesu)' zum Ausdruck), cf. also p. 79f.

40 The title of this section outlines a known and difficult problem in need of solving: how to interpret sôma and sarx in Polish? As this does not constitute our basic theme we will refer only outline this problem.

41 Cf. e.g. M.I. Alves, Il cristiano in Cristo. La presenza del cristiano davanti a Dio secondo S. Paolo, Braga 1980, 48f, J.F. Collange, Enigmes de la deuxiéme épître de Paul aux Corinthiens. Étude exégétique de 2 Co 2,14-7,4, Cambridge 1972, 55f and by the same author Lépître de saint Paul aux Philippiens, Genève [1987], 230; H.H. Schade, Apokalyptische, 147; E. Käsemann, 
Previously we outlined the issue related to the expressions of this type: "in Adam," "in death," "in Law" / "in law." At least grammatically they seem to be close to the expressions "in body" (en sômati and en sarki). In this way also, the latter ones may help us, e.g. to better explore the meaning of the wordings "in Christ" in the writing by St. Paul, also what the latter ones tell us about our temporal life as life in Christ ${ }^{42}$. Considering, e.g. the similarities and semantic relations between the terms sôma and sarx it seems justifiable to us to present the wordings "in body (en sômati and en sarki) together ${ }^{43}$.

In Corpus paulinum, as for the so-called authentic epistles of St. Paul, we come across the expression of this type: 'in body' (en sômati) in the following texts ${ }^{44}$ : Rom 6:12 ("may a sin reign then in your deadly body so that you will not have to succumb to its passion"), Rom 12:4 ("because we have many parts in our body, and they all do not fulfil the same task"), 1Cor 6:20 ("then worship God in your body) 45, 1Cor 12:18 ("now while God created body parts, each of them in your body [just as] he wanted"), 1Cor 12:25 ("so that there was no tear in body, but so that particular parts cared about each other), 2Cor 4:10a ("we are continually carrying death of Jesus in our body"), 2Cor 4:10b ("may the life of Jesus revealed in our body) ${ }^{46}$, 2Cor 5:6 ("having constant faith we

op. cit., 184; R. Schnackenburg, Signoria e Regno di Dio. Uno studio di teologia biblica, Bologna 1971, 308.

${ }^{42}$ Cf. e.g. W. Elliger, en, in: Exegetisches Wörterbuch zum Neuen Testament. Herausgegeben von Horst Balz - Gerhard Schneider. Band 1 Aarôn Henoch, Stuttgart Berlin - Köln - Mainz 1980, 1095; M.I. Alves, Il cristiano in Cristo, 48f; J.F. Collange, Énigmes de la deuxième épître de Paul aux Corinthiens, 55 and by the same author Lépître de saint Paul aux Philippiens, 230.

${ }^{43}$ Cf. e.g. the sentence by H. Mehl-Kóhnlein, Lhomme selon lapôtre Paul, Neuchâtel Paris 1951, 17: a man is a being marked by the past, he is, e.g. a successor of the sin committed by Adam; hence in 'man-according to-nature' ("homme naturel"), according to this author in the end a permeating of the aspects expressed by the words sôma and sarx takes place (cf. p. $12 \mathrm{f}$ and 36). It is obvious that we will not be able to devote appropriate attention to broad and complex issues related to the terms sôma oraz sarx; more on this issue: cf. e.g. E Neugebauer, In Christus, 53; Vocabulaire de théologie biblique, 146n, 210n, 213n; E. Schweizer, F. Baumgartel, sôma etc., TWNT7, 1024n; Kreitzer, Body, 71f; R.Y.K. Fung, Body of Christ, 77f; E. Schweizer, F. Baumgärtel, R. Meyer, sarx etc., TWNT 7, 98n; R.J. Erickson, Flesh, 303f; M. Lurker, Carne, in: M. Lurker, Dizionario delle immagini e dei simboli biblici. Edizione italiana a cura di Gianfraco Ravasi, Torino 1994, 38 and R. Cavedo, Corporeitâ, in: Nuovo dizionario di teologia biblica a cura di Pietro Rossano etc., Torino 1994, $308 \mathrm{f}$.

44 As for the New Testament we also need to enumerate: Ephesians 2:16; Colossians 1:22; 3,15; To the Hebrews 13:3 and P 2:24.

45 Cf. critical apparatus.

46 As for the expression en tô sômati in the afore-mentioned line, cf. also critical apparatus. 
know, remaining in body we remain far from Lord"), 2Cor 12:2 ("I know a man in Christ, who fourteen years ago, whether in body, I do not know, or out of body, I do not know, God knows, was kidnapped as far away as to the third heaven"), 2Cor 12:3 ("I know that this man, whether in body or out of it, I do not know, God knows it"), Gal 6:17 ("because I [literally: in] carry marks of Christ on my body"), Phil 1:20 ("Christ will be adored in my body).

In Rom 12:4 and in 1Cor 12:18.25 the Apostle refers to the wording "in body" (en sômati) to talk about unity of Christ's disciples. In body, which is one, as if we could say today "in an organism," there are different parts, different limbs, which complement each other, fulfil different tasks and this is possibly the most important thing, one in favour of others (cf. Rom 12:4 and 1Cor 12:18.25). Similarly, Christ's disciples, being so different, constituting, in the full meaning of this word, and with all consequence of this fact, separate people, create just one body in Christ (cf. e.g. Rom 12:25: "similarly numerous we are one body in Christ, one is the part of the other").

Another group of texts, which should be distinguished here, is pericopes, where the term "body" (sôma) corresponds to our definition of "(human) body," most probably becoming more and more almost a synonym of a word "person" in the contemporary meaning of this term ${ }^{47}$. Christians, already nowadays, having died for sin live for God in Jesus Christ (cf. Rom 6:11) ${ }^{48}$. It means that a sin cannot Reign in their body any longer - even if the latter is to experience the power of death (cf. Rom 6:12: "may then a sin not reign in your deadly body, so that [you] will not be succumbed to its lust," cf. also 7: 14-24 and 1Cor 6:13-14). They should already worship God in their body (worship God in your body, 1Cor 6:20). Their body belongs to Lord (cf. 1Cor 6:13-14) and is the temple of the Holy Spirit (cf. 1Cor 6:19). St. Paul writes about himself, and possibly also about someone from his co-workers (cf. e.g. 2Cor 1:1) that he carries death of Jesus in his body (2Cor 4:10a), so that the life of Jesus could reveal in our body (1Cor 4:10a, cf. line 11). He carries marks (Greek: ta stigmata) of belongingness to Christ on his body (literally: "in") (Gal 6:17). The Saviour will be adored "in the body" of Apostle: is it through life or through death (cf. Phil 1:20, cf. line 21).

The wording "in body" (en sômati) may also have a negative connotation. In this way, e.g. "remain in body" means for a Christian "to be far from Lord,"

47 Cf. e.g. E. Käsemann, op. cit., 119; R. Bultmann, Das Problem der Ethik bei Paulus, ZNW 23(1924)137; M.I Alves, Il cristiano in Cristo, 217; H. Mehl Köhnlein, Lhomme selon lapôtre Paul, 9f and 36; F. Neugebauer, In Christus, 52f; U. Luz, op. cit., 227.

48 Cf. also e.g. Romans 6:6: "then you should know that to destroy a body of sin, our old man was crucified with Him, so that we were not in the captivity of sin anymore." 
"not achieve one's goal yet," "to be a pilgrim" (cf. 2Cor 5:6: "remaining in body we remain far from Lord").

Let us also state in this context 2Cor 12:2-3, where à propos received revelations and visions (line 1), the Apostle writes that "he was kidnapped to the third heaven." St. Paul characterises this event, among others, by using two almost identical expressions. We could provide them in Polish - as for the aspect we are interested in - through: "whether in body I do not know, whether out of body - I do not know" (line 2 and 3 ).

The wordings "in body" (en sarki) in Corpus paulinum, in the so-called "authentic epistles of St. Paul" may be found in the following texts ${ }^{49}$ : Rom $2: 28$ ("either circumcision is not [it is which it is] visible on [literally: in] body"), 7:5 ("because when we were in body"), 7:18 ("I know that he does not live in me, that is in my body, good: because it is easy to want it, however I do not do something which is good"), 8:3 ("and for [the removal] of sin he gave a judgment in body, which condemned a sin"), 8:8 ("those who are in body, cannot be liked by God"), 8:9 ("you, however, are not in body, but in Spirit [or: in spirit]"); 2Cor 4:11 ("may also the life of Jesus reveal in our deadly body"), 10:3 ("when living in body we do not fight according to body"); Gal 2:2 ("I do not live anymore, Christ lives in me: although I still live in body, I live in faith of God's Son, who loved me and gave himself for me"), 4:14 ("and you neither regard my attempt in body as anything nor you rejected it with disgust, but you took me over as God's angel, as Jesus Christ"), 6:12 ("those who present well in body, who force you to circumcise, only not to be persecuted because of Christ's cross"), Gal 6:13 ("to boast in your body"); Phil 1:22 ("if I live in body, it is fruitful work for me"), 1:24 ("to remain in body - it is more necessary for you") ${ }^{50}, 3: 3$ ("when we are already circumcised, those who officiate liturgy with the Holy Spirit and we boast in Jesus Christ, and we do not behave according to body [literally: in body]), 3:4a ("although and I can place my trust also in body"), Phil 3:4b ("if somebody else thinks to place trust in body, I think more about it"), Philemon 16 ("not as a slave anymore, but more than a slave, adored brother, particularly for me, but much more for you in body and in Lord").

Rom 8:3 may be alternatively included in the group above in its similarity to the body in sin.

49 As for the New Testament, we need to also enumerate the following texts: Ephesians 2:11ab, Colossians 1:24; 2:1; 1 Timothy 3:16 as well as 1 Peter 4:2; 1 Jude 4:2 and 2 Jude 7.

50 As for the wording "in body" (en sarki) in this text, cf. also critical apparatus. 
In such texts as: Rom 2:28, Gal 4:14; 6:13, Phil 1:22.1:24 the term sarx may be translated into Polish as "body" 1 . The same may be understood by the word discussed also in 2Cor 4:11; 10:3; Phil 1:22; 3:4ab; Gal 6:12 and Philemon 16.

As for such pericopes as Rom 7:18 and probably 2Cor 4:11, the term sarx would probably correspond best to our definition of "person" (obviously in the contemporary meaning of this word $)^{52}$.

On the other hand, in the texts, which will be enumerated by us now, the expression "body" ( $\operatorname{sar} x$ ) may serve the Apostle to reflect the idea of certain orders or even more of one's belongingness to it ${ }^{53}$. According to Rom 8:8 those, who are "in body," cannot be liked by God. For St. Paul Christians are no longer "body," but "in Spirit" - "in spirit" 54 (Rom 8:9; cf. also 2Cor 10:3). We would have to deal with two orders and opposite to each other (cf. e.g. "but", Greek: alla in Rom 8:9). A man belongs to these orders in temporality as well. As for the first one, then a man experiences the captivity in it. Death is his end: „when we were in body, we were subject to sinful lusts existing in us and fed by Law and bringing fruit, which brought death" (Rom 7:5) ${ }^{55}$. Gal 2:20 also allows for a similar interpretation of the wording "in body" (en sarki) in the sense of regime, which gave way (or is giving way) to new order introduced by Christ ${ }^{56}$ :

it is not me who lives anymore although I live in body
Christ lives in me

I live in faith, [in faith] of God's Son

For its part, Gal 2:20 somehow "comments" the texts from 2 Corinthians 10,3. According to the latter, in temporality Christians in a certain way still remain "in body", they live in its order, developing in body, but not fighting according to body. The latter did not experience all the consequences of work

51 As was already outlined, we cannot deal with the broad and incredibly difficult task to reflect on the difference between the words sarx and sôma in Polish here. As far as it is reasonably possible, we will remain with their translation of 'ciało' (Eng. body).

52 Cf. H, Mehl-Kóhnlein, Lhomme selon lapôtre Paul, 12-13 as well as P.H. Menoud, op. cit., 36 .

53 Cf. E. Käsemann, op. cit., 120 .

54 We deliberately provide the wordings 'in Spirit' - 'in spirit': in this way we may preserve the richness of the very text, not confining ourselves to the meaning of the expression: en pneumati ('in Spirit' / 'in spirit') to one explanation.

55 Cf. Romans 7:4.6: (4) so and you, my brothers, thanks to body of Christ, died for Law, to be united with others - with the One, who rose from the dead, so that we could bring fruit to God. (6) Now Law lost its power over us, when we died for this, which kept us in captivity, so that we can fulfil our service in new Spirit, and not according to the obsolete letter.

${ }_{56}$ Cf. H. Schlier, Der Brief, op. cit., 276 and G. Bornkamm, Taufe..., op. cit., $34 f$. 
already done by Christ (cf. e.g. Phil 1:22.24 as well as 1Cor 15:35n.51n and Phil 3:21). However, a man is already, he already lives in the order of the reign of the Saviour. ${ }^{57}$ And the last one is a decisive factor - although due to Divine disposition - the old regime does not totally belong yet to a domain of the past and it may still influence both a man and the fate of the world. This is how we may present what the Apostle writes about it in 2 Cor 10:3:

because in body not according to body

developing fighting

Christians do not put confidence in body anymore - even if it was possible $e^{58}$ - but they boast in Jesus Christ: because circumcision means us, who by means of the Holy Spirit officiate liturgy and boast in Jesus Christ and we do not put confidence in body (Philippians 3:3; cf. also Galatians 6:13: those want to present well in body, who force to circumcise, just not to be persecuted due to Christ's cross). Those, who believe in Christ and belong to Him, pin their hope just in their Lord. ${ }^{59}$ This hope does not only refer to the past. It is related to transitions, which complement before our eyes just now, that is in temporality. The following fact noticed by Saint Paul may be an example of this. For his lord, Philemon, a slave Onesimus becomes an adored brother and as a man and as a Christian, equally well in order of nature and in order of grace: already as somewhat a slave, but more than a slave, an adored brother, particularly for me, even more for you, and in body and in Lord (Philippians 16). Thus, in some way, temporality still remains itself. The old order in "body" (en sarki) is still present and important. It is not, however, something absolute. It is somewhat complemented by the new order "in Lord". The latter surpasses the former, constitutes its goal and accomplishment. ${ }^{60}$

The texts presented above present how the terms "body" (sôma) and "body" (sarx) may have different meanings and applications. They may serve for talking about something which is positive and about something which is negative. They

57 Cf. e.g. Romans 7:5.18n and 8:8-9 as well as Romans 6:4; 8:4; 2 Corinthians 10:2. Cf. also E. Lohmeyer, Probleme paulinischer Theologie, Stuttgart 1955, 102-106 and 118, R. Penna, Lo Spirito di Cristo. Cristologia e pneumatologia secondo un'originale fôrmulazione paolina, Brescia 1979, 249f; P.H. Menoud, op. cit., 33.

${ }_{58}$ Cf. Philippians 3:4a (and I can put confidence in the body) and $4 \mathrm{~b}$ (if someone else think that they may put confidence in the body, so I can do it even more); cf. also 3:7n.

59 Cf. Romans 14:14 (I know, and I am convinced in Lord Jesus); Galatians 5:10 (I have confidence in Lord about you); Philippians 1:14 (and so more brothers emboldened in Lord by my chains dare more without fear to preach the word); 2:24 (I trust in God).

${ }^{60}$ Cf. R. Penna, Lo Spirito di Cristo, 249f. 
preserve great "flexibility" and many semantic "nuances" as far as e.g. the qualitative evaluation of a given aspect is concerned. Sometimes it is even difficult to declare for only one interpretation and conduct a clear-cut classification.

At least some outline texts with the wordings: "in body" (en sômati) and "in body" (en sarki) allow for talking about a certain order, regime, which is much more than different from the order of grace. We could talk here about opposition, conflict or even about mutual exclusion. ${ }^{61}$ As for the order of grace, we could call it "order in Christ". ${ }^{6}$

\section{Conclusion}

The wordings presented by us do not belong to the most popular either in the New Testament or in the afore-mentioned so-called authentic epistles of St. Paul the Apostle. It does not mean, however, that they do not have those meanings. God's word, also by their assistance, tells us about our human life. At this current stage, we did not manage to possess this gift in full, which eternally stays with God, or eternal salvation. Simultaneously, we are aware, however, that together with the coming of Christ, our situation radically changed for the better. We are not slaves anymore of such powers as sin or death. It is true that our liberation is neither complete nor final yet. We cannot go to the other extreme, however, and not to admit that we do not belong to them, that Life stays behind us, that He is already an absolute Lord now and Lord of us, ourselves and of all this, which was created (cf. e.g. Philippians 3:21). In other words, following the Apostle of nations, we could describe our current situation in the following way. As Christians we are already in Christ (Greek: en Christô). In temporality, however, we are the successors of Adam: just as if our fates became "closed", "programmed" in Adam. We remain beings limited by Death. We still and continually experience a frightening burden of its reign. Repeating the words of St. Paul we may reflect this aspect of our existence in temporality, reaching for the expression "in death" as we still belong in its zone. We also "live" in it in some way. However, this is not everything. Our temporal life also has other aspects. Thus, to reflect on them, the Apostle will refer to the mystery of law / Law and to the mystery of what is material, in particular in man himself, to the

${ }^{61}$ Cf. e.g. E. Käsemann, op. cit., 120; H. Mehl-Köhnlein, L'homme selon lapôtre Paul, $14 f$.

62 Cf. W. Elliger, en, 1095; A. Schweitzer, La mystique de l'Apôtre Paul, 116f and 122. 
mystery of thebody (Greek: sôma and sarx).$^{63}$ As we noticed, also the last three may be something negative, captivating a man, not least serving for his good. A man, waiting for his meeting with Christ, or already living with this meeting, is also a living being, also in a pejorative sense, in body (en sômati and en sarki). We can state the same about another of God's gifts, about law / Law, as well as about order, which the Apostle reflects on by the expression "in law" / in Law". As we noticed, such a defined image is not unanimously negative. A man living in a described situation has not lost his chance yet. He needs salvation and may obtain it. When it occurs, his situation changes. The transition is radical, although usually a given person gradually experiences it. It is often divided into their entire life. Most frequently the old order does not disappear at once. It becomes partially abolished, annihilated. It partially becomes transformed, cured. It partially influences us as well. Our temporality is such. And just as such, it constitutes time and place of salvific work of God and an integral part of the Divine economy. And it frequently outgrows our potential of understanding, reminding us at the same time about the place and role of faith, hope and love.

One of the aspects of the Pauline vision of salvific work could be presented in a great outline in this way. It is noticeable in a specific, interesting way in the wordings we come across in e.g. the so-called authentic epistles of St. Paul the Apostle. This, expressed by them, being God's Word, refers not only to people living in the Apostle's time. It concerns people of all times. It concerns us also.

63 As was outlined above, we deliberately do not discuss the problem of the interpretation of such terms as: nomos ("Law" / "law"), sôma ("body") and sarx ("body"). The problem is broad and complex. It is easy to present simplifications, and as a result to deliberately impoverish the inspired text. In just this context we will refer to an interesting issue worthy of consideration, although directly referring to another issue, the opinion by L. Cerfaux (Le Christ dans la théologie de saint Paul, 223): "Il n'est pas toujours possible, ou il n'est daucune utilité, d’assigner la limite exacte d'un terme. Le mieux est d'entendre chaque formule avec l'imprécision qu'elle avait dans l'esprit de saint Paul. L'imprécision est signe de richesse et non de pauvreté: Paul envisageait en gros tout ce que comporte de virtualités les notions d'Esprit et de spirituel." 